\title{
KUALITAS PELAYANAN PENYALURAN BANTUAN RASKIN DI KELURAHAN PANARUNG KOTA PALANGKA RAYA
}

\section{Quality of Service for Distribution of Raskin Assistance in Panarung Village, Palangka Raya City}

\section{Muhamad Yusuf* \\ Novia Lestari}

Universitas Muhammadiyah Palangkaraya, Palangka Raya, Central Kalimantan, Indonesia

email:

yusuf.quratayun@gmail.com

\section{Kata Kunci:}

Kualitas Pelayanan

Penyaluran Bantuan

Raskin

\section{Keywords:}

Service quality

Distribution of Assistance

Raskin

\section{Accepted}

June 2016

\section{Published}

October 2016

\begin{abstract}
Abstrak
Penelitian ini bertujuan untuk menggambarkan dan mendeskripsikan Kualitas Pelayanan Penyaluran Bantuan Raskin Di Kelurahan Panarung Kota Palangkaraya. Metode penelitian yang digunakan adalah kualitatif dimana peneliti ingin menggambarkan dan mendeskripsikan tentang Kualitas Pelayanan Penyaluran Bantuan Raskin Di Kelurahan Panarung Kota Palangkaraya, Sumber Data yaitu Seksi Kesejahteraan Sosial dan Pelayanan Masyarakat, seksi Pembangunan dan Sumber Daya Manusia (SDM) dan seksi Pemerintahan. Berdasarkan hasil penelitian yang sudah dilakukan bahwa Kualitas Pelayanan Penyaluran Bantuan Raskin Di Kelurahan Panarung Kota Palangkaraya sudah cukup baik dan pelaksanaannya sudah mengikuti prosedur yang sudah ditetapkan, namun masih belum maksimal, itu karena sosialisasi yang belum maksimal diberikan, sarana yang kurang memadai, kedisiplinan petugas, itu yang membuat pelayanan menjadi lambat.
\end{abstract}

\section{PENDAHULUAN}

Pemerintah daerah sebagai penyedia layanan publik senantiasa dituntut kemampuannya meningkatkan kualitas layanan, mampu menetapkan standar layanan yang berdimensi menjaga kualitas hidup, melindungi keselamatan dan kesejahteraan rakyat. Seperti halnya di kantor kelurahan panarung kota Palangkaraya dimana banyak fenomena-fenomena yang menarik yang berkaitan dengan masyarakat miskin, pemerintah sudah membuat program untuk masyarakat miskin diantaranya program Bantuan Langsung Tunai (BLT), program beras bersubsidi untuk rumah tangga miskin (Raskin), pembagian tabung gas dan kompor gas LPG
(Liquefied Petroleum Gas), Jaminan Kesehatan Masyarakat (JAMKESMAS), program Keluarga Bencana (KB) dan lainnya. Namun ada beberapa kejanggalankejanggalan yang saya lihat diantaranya masalah pembagian beras bersubsidi untuk rumah tangga miskin (raskin) dimana yang seharusnya terdaftar dalam penerimaan raskin tersebut hanya untuk masyarakat miskin atau kurang mampu tapi pada kenyataannya banyak yang berbeda dari data yang sudah ditentukan dan tidak sesuai harapan. Begitu pula dengan program pembagian kompor gas LPJ.

Kualitas merupakan suatu kondisi dinamis yang berhubungan dengan produk, jasa, manusia, proses, 
dan lingkungan yang memenuhi atau melebihi harapan (Tangkilisan,2005:209). Dari pengertian tersebut, kualitas mengandung elemen-elemen yang meliputi usaha memenuhi atau melebihi harapan pelanggan, yang mencakup produk, jasa, manusia, proses, dan lingkungan serta merupakan kondisi yang selalu berubah. Sedangkan menurut Sinambela, dkk (2006: I3) "kualitas adalah segala sesuatu yang mampu memenuhi keinginan atau kebutuhan pelanggan.

Menurut Kotler (Lukman,2000:8) pelayanan merupakan setiap kegiatan yang menguntungkan dalam suatu kumpulan atau kesatuan, dan menawarkan kepuasan meskipun hasilnya tidak terikat pada suatu produk secara fisik. Sementara itu menurut Sampar, pelayanan merupakan suatu kegiatan atau urutan kegiatan yang terjadi dalam interaksi langsung antar seseorang dengan orang lain atau mesin secara fisik, dan menyediakan kepuasan pelanggan. Menurut Rappaport (Totok Mardikanto 2015:29) "Pemberdayaan adalah suatu cara agar rakyat, komunitas, dan organisasi diarahkan agar mampu menguasai atau berkuasa atas kehidupannya". Menurut Kementerian dan Bidang Kesejahteraan Rakyat (Lembar Informasi dan Sosialisasi Program Raskin) Program Raskin adalah salah satu program penanggulangan kemiskinan dan perlindungan sosial yang diselenggarakan oleh pemerintah pusat berupa bantuan beras bersubsidi kepada rumah tangga berpendapatan rendah.

\section{METODOLOGI}

Metode Penelitian Kualitatif adalah metode yang lebih menekankan pada aspek pemahaman secara mendalam terhadap suatu masalah dari pada melihat permasalahan untuk penelitian. Sedangkan Penelitian Kualitatif adalah suatu penelitian yang ditujukan untuk mendeskripsikan dan menganalisis fenomena, peristiwa, aktivitas sosial, sikap, kepercayaan, persepsi, pemikiran orang secara individual maupun Kelompok.

\section{HASIL DAN PEMBAHASAN}

Berdasarkan hasil penelitian dan pembahasan yang telah dilakukan dalam penelitian ini, bahwa kualitas Pelayanan Penyaluran Bantuan Raskin di Kelurahan Panarung sudah cukup berkualitas, hal ini dapat dijabarkan dari masing-masing indikator sebagai berikut:

I. Tangible (berwujud), dari tampilan kondisi fisik maupun sarana dan prasarana dalam hal ini indikator tangible masih rendah dengan kondisi ruang pelayanan yang sempit, kursi tempat ruang tunggu juga terbatas namun dalam hal kerapian petugas sudah cukup baik dalam artian petugas selalu berpakaian seragam lengkap yang sudah ditentukan dari Pemerintah.

2. Reliability (kehandalan), dari segi kehandalan baik itu dari kesediaan dan kecermatan petugas dalam memberikan pelayanan kepada masyarakat cukup baik. Tetapi dari segi informasi/sosialisasi yang mendalam tentang penyaluran bantuan raskin ini masih kurang, baik itu dari informasi ke RT maupun masyarakatnya.

3. Responsiviness (ketanggapan), dari segi ketanggapan dan kecepatan pun cukup baik, dan dalam memberikan informasi kepada masyarakat sudah jelas, petugas sangat bijak dalam mengatasi masalah jika ada keluhan dari masyarakat dan jika ada kesalahan langsung ditangani petugas dengan cepat.

4. Assurance (jaminan), dalam indikator ini petugas menjamin bahwa pelayanan yang diberikan sudah sesuai dengan data yang benar dan petugas juga sangat ramah, baik dan tegas.

5. Empathy (empati), dalam indikator ini terkait sikap tegas tetapi penuh perhatian sebagian petugas kelurahan terhadap masyarakat yang kurang karena mereka terlalu sibuk berbincang dengan rekan kerjanya atau sibuk mengerjakan pekerjaannya masing-masing. 


\section{KESIMPULAN}

Tangible (berwujud), dari tampilan kondisi fisik maupun sarana dan prasarana dalam hal ini indikator tangible masih rendah. Reliability (kehandalan), dari segi kehandalan baik itu dari kesediaan dan kecermatan petugas dalam memberikan pelayanan kepada masyarakat cukup baik. Responsiviness (ketanggapan), dari segi ketanggapan dan kecepatan pun cukup baik, dan dalam memberikan informasi kepada masyarakat sudah jelas. Assurance (jaminan), dalam indikator ini petugas menjamin bahwa pelayanan yang diberikan sudah sesuai dengan data yang benar dan petugas juga sangat ramah, baik dan tegas. Diharapkan kepada pihak kelurahan agar dapat menambah sarana dan prasarana yang diperlukan dalam proses pelayanan sebagai contoh penambahan tempat ruang tunggu, tempat duduk untuk menunggu dan peralatan lain yang menunjang kualitas pelayanan terhadap masyarakat. Diharapkan kepada petugas Kelurahan Panarung agar mensosialisasikan/ menginformasikan lebih mendalam tentang pembagian raskin kemasyarakat agar masyarakat lebih paham jika ada kesalahan dari RT-nya. Diharapkan kepada petugas Kelurahan Panarung agar tidak bersikap diskriminatif atau membeda-bedakan dalam memberikan pelayanan.

\section{REFERENSI}

Asrinaldi, 2012. Politik Masyarakat Miskin Kota. Yogyakarta : Gava Media

Bank, The World, 20I2. Pedoman Tentang Kemiskinan dan Ketimpangan. Jakarta : Salemba Empat.

Gunawan, Imam, 20I4. Metode Penelitian Kualitatif; Teori da Praktik. Jakarta : Bumi Aksara

Hardiyansyah, 20II. Kualitas Pelayanan Publik; Konsep, Dimensi, Indikator dan Implementasinya. Yogyakarta : Gava Media

Ibrahim, Amin, 2008. Teori dan Konsep Pelayanan Publik serta Implementasinya. Bandung : Mandar.
Laksminarti, L. 2016. Implementasi Peraturan Daerah No 9 Tahun 2012 Tentang Penanganan Gelandangan, Pengemis, Tuna Susila Dan Anak Jalanan Di Kota Palangka Raya Provinsi Kalimantan Tengah. Restorica: Jurnal Ilmiah Ilmu Administrasi Negara dan Ilmu Komunikasi. 2(I):31-40.

Lukman, Sampara. 2000. Manajemen Kualitas Pelayanan. Jakarta: STIA LAN Press.

Mardikanto, Totok \& Poerwoko Soebiato, 2015. Pemberdayaan Masyarakat. Bandung : Alfabeta

Nawawi, Zaidan, 2013. Manajemen Pemerintahan. Jakarta : PT Raja Grafindo Persada.

Pasolong, Harbani, 2008. Teori Administrasi Publik. Bandung : Alfabeta

Ratminto \& Atik. 2005. Manajemen Pelayanan. Yogyakarta : Pustaka Belajar

Sinambela, Lijan Poltak, 2012. Kinerja Pegawai; Teori, Pengukuran dan Implikasi. Yogyakarta : Graha IImu.

Sinambela, Lijan Poltak, dkk, 2006. Reformasi Pelayanan Publik, Teori, Kebijakan dan Implementasi. Jakarta : Bumi Aksara.

Tangkilisan, Nogi Hessel. 2005. Manajemen Publik. PT. Gramedia Widiasarana Indonesia : Jakarta.

Toun, N.R., Candra, E.S. 2016. Model Perumusan Kebijakan Elit Transformasional Pada Perencanaan Pembangunan Masyarakat (Studi Perencanaan Pembangunan Di Desa Tumbang Liting). Pencerah Publik. 3(2):9-I8. 